\title{
Investigation of contamination pathway and human health risk assessment from metals in milk from the cows grazing in an industrial area: a mass balance approach
}

Muthyala Sai Chaithanya

Vellore Institute of Technology: VIT University

Bhaskar Das ( $\sim$ bhaskar.ju@gmail.com )

VIT University https://orcid.org/0000-0002-0794-1677

Vidya $\mathbf{R}$

Vellore Institute of Technology: VIT University

\section{Research Article}

Keywords: Cancer risk, Cow milk, Hazard index, Metal contamination, Shallow Lake

Posted Date: April 30th, 2021

DOl: https://doi.org/10.21203/rs.3.rs-462351/v1

License: (c) (i) This work is licensed under a Creative Commons Attribution 4.0 International License.

Read Full License 


\section{Investigation of contamination pathway and human health risk assessment from metals \\ 2 in milk from the cows grazing in an industrial area: a mass balance approach}

3 Muthyala Sai Chaithanya ${ }^{\mathrm{a}}$, Bhaskar Das ${ }^{\mathrm{a}, 1}$ and Vidya $\mathrm{R}^{\mathrm{b}}$

$4 \quad{ }^{a}$ Department of Environmental and Water Resources Engineering, School of Civil Engineering (SCE), Vellore

5 Institute of Technology, Vellore, Tamil Nadu 632014, India

$6{ }^{b}$ VIT School of Agricultural Innovations and Advanced Learning (VAIAL), Vellore Institute of Technology,

7 Vellore, Tamil Nadu 632014, India

8 Correspondence details:

9 Dr. Bhaskar Das, Associate Professor

10 GDN-142, Environmental Engineering Laboratory, Department of Environmental and Water Resources

11 Engineering, School of Civil Engineering (SCE), Vellore Institute of Technology, Vellore, Tamil Nadu 632014,

12 India.

13 Email: bhaskar.ju@gmail.com; ORCID: 0000-0002-0794-1677

14 Muthyala Sai Chaithanya, Ph.D scholar,

15 GDN-142, Environmental Engineering Laboratory, Department of Environmental and Water Resources

16 Engineering, School of Civil Engineering (SCE), Vellore Institute of Technology, Vellore, Tamil Nadu 632014,

17 India.

18 Email: chaithu.146@gmail.com

19 Dr. Vidya R, Senior Assistant Professor,

20 VIT School of Agricultural Innovations and Advanced Learning (VAIAL), Vellore Institute of Technology,

21 Vellore, Tamil Nadu 632014, India.

22 Email: rvidya@vit.ac.in

\footnotetext{
${ }^{1}$ Corresponding Author (bhaskar.ju@gmail.com)
} 
The water bodies within the industrial areas are often used for the disposal of effluents leading to heavy metal contamination in water, soil, and vegetation. However, the impact of this metal enrichment on the food web has not been much explored. The present study investigates the food chain contamination of eight metals $(\mathrm{Al}, \mathrm{Cd}, \mathrm{Cr}, \mathrm{Cu}, \mathrm{Fe}, \mathrm{Mn}, \mathrm{Pb}$, and $\mathrm{Zn}$ ) in the milk from the cattle grazing on a shallow lake bed within the industrial town of Ranipet, India, and associated health risk from the consumption in adults and children. The average concentrations were found to be 24.93, 7.08, 3.31, 0.18, 0.12, 0.08, 0.014, and 0.008 in $\mathrm{mg} / \mathrm{L}$ for $\mathrm{Zn}, \mathrm{Al}, \mathrm{Fe}, \mathrm{Cr}, \mathrm{Pb}, \mathrm{Mn}, \mathrm{Cu}$, and $\mathrm{Cd}$, respectively. The hazard indices ranged from 0.55 to 1.85 for children; the Incremental Lifetime Cancer Risk (ILCR) values of $\mathrm{Cd}$ and $\mathrm{Cr}$ were above 10-4 for consumption of milk in both adults and children, which signify serious health risk. The mass balance evaluates the primary intake of all the metals, except $\mathrm{Al}$, are from forage; where for $\mathrm{Al}$ it is from the soil. The existing milk consumption patterns projected that 531 children and 1279 adults, drinking contaminated milk are at considerable risk. The analyses of tail switch hair samples indicated the cattle are also environmentally exposed to metals indicating their subclinical effect. Hence the study alerts the elevated and often overlooked risk associated with the food chain contamination from milk in the industrial belt and recommends stringent quality control and monitoring.

Keywords: Cancer risk; Cow milk; Hazard index; Metal contamination; Shallow Lake.

\section{Declarations}

\section{Funding}

46 The research was financially supported by Department of Science and Technology-Science and Engineering

Research Board (DST-SERB) under project DST/EMR/2016/006662.

\section{Conflicts of interest/Competing interests}

The authors declare that they have no conflict of interest.

\section{Availability of data and Material}

51 The switch-tail hair metal concentrations and risk estimation are not included in the manuscript can be found at: request. 


\section{Code availability}

$55 \quad$ Not applicable

\section{Acknowledgements}

57 The authors acknowledge the help of Department of Science and Technology-Science and Engineering Research

58 Board (DST-SERB) for the financial support provided for this study and Vellore Institute of Technology (VIT)

59 for providing necessary laboratory facilities to carry out this work.

\section{Ethics approval}

61 All of the experiments were carried out in compliance with the standards of international, state, and/or institutional

62 animal care and use guidelines. There are no experiments involving human participants in this article. The

63 manuscript has not been submitted or published in any form, in part or in whole.

\section{Consent to participate}

65 All the samples were collected with the consent of the owners to use in this study. No animal was harmed during 66 the collection of the samples.

\section{Consent for publication}

68 All the authors have read and approved the paper for submission of journal.

69 
79 Rapid urbanization coupled with industrial and agricultural activities have resulted in the exponential increase of

80 pollutants released into the environment. Among them, metals pollution are significant due to their 81 bioaccumulation and prolonged persistence in the environment (Lin et al. 2016). However, several metals such as 82 chromium, copper, iron, manganese, zinc etc. are essential for human metabolism in small quantity, but excess concentrations can cause chronic health effects (Al osman et al. 2019; Giri and Singh 2020). Other metals like cadmium, lead, mercury, etc. aren't essential and cause detrimental effects on human health even at lower levels (Zhang et al. 2017). Metals can be easily accumulated into plants grown on contaminated soils. Thus, significant amount of metals can be transferred from contaminated soil to plants and grass, causing accumulation in grazing ruminants, especially cattle. Moreover, accumulation of these metals can cause toxic effects in cattle; but also in humans consuming metal contaminated milk and meat (Pilarczyk et al. 2013; Giri and Singh 2020; Pšenková et al. 2020).

The milk and its products are basic foods with essential source of nutrients in daily human diet, especially infants. Among them the cow milk is considered as one of the greatest nutritional valued food as being vital in children's diet (Castro Gonzalez et al. 2017). So, the metal content in the milk can be a significant indicator of food hygiene as well as degree of contamination (Licata et al. 2012). Further, the children are more vulnerable than adults to acute toxicity at lower doses as their defence mechanisms aren't completely developed. Due to their undergoing developmental processes, the acute or chronic exposures can lead to serious anomalies which can either persist or develop at later age (Scheuplein et al. 2002). Hence the contamination of cattle milk is a matter of increasing concern and need to be addressed without any tolerance.

The metal contamination of milk has been reported earlier in many parts of the world; especially due to 100 anthropogenic activities (Castro Gonzalez et al. 2017; Yasotha et al. 2020; Boudebbouz et al. 2021). Zhou et al.

101 (2019) reported that the milk samples were contaminated with $\mathrm{Pb}$ from industrially polluted area in Tangshan 102 province, China. Iqbal et al. (2020) reported that metals like $\mathrm{Cd}, \mathrm{Cr}, \mathrm{Cu}, \mathrm{Mn}$ and $\mathrm{Pb}$ were present in buffalo milk samples collected from agricultural farms irrigating with industrial wastewaters in Multan city, Pakistan. Further,

104 significant carcinogenic risk was reported for all age groups (adults and children) by consumption of the milk 105 from this area. There are several studies of milk contamination from India especially from industrial and mining 106 areas. Giri and Singh. (2019) reported significant health risks by consumption of milk from locally rearing cows in vicinity of copper mining and processing industries in Singhbhum of Jharkhand state. Raghu (2015) reported 
108 that the milk samples from a barite mining site in Kadapa District, Andhra Pradesh were significantly

109 contaminated with $\mathrm{Ba}, \mathrm{Co}, \mathrm{Sr}$ and $\mathrm{Zn}$. Yasotha et al. (2020) reported that the milk samples collected from the

110 cows reared in industrial areas of Erode District, Tamil Nadu were contaminated with $\mathrm{Cd}, \mathrm{Cr}, \mathrm{Pb}$ and $\mathrm{Zn}$. Hence,

111 from the literature, it was evident that metals pave their way through contaminated forage/water to the cattle;

112 eventually into the milk and subsequent food chains.

113 Soil was considered as sink of metals and the exact anthropogenic metal contribution was due to

114 discharge of industrial effluents. The ruminants grazing in the industrially influenced areas has different sources

115 for metal intakes such as contaminated water, forage and soil (Zhou et al. 2019; Iqbal et al. 2020). The soil

116 ingestion while grazing was out looked by most of the studies as they often consider milk contamination and

117 associated health risks; which need to be explored. Also, the quantified contribution of metals from the different

118 intake sources to the milk is not apprehended properly. Hence, for the detailed understanding, mass balance needs

119 to be evaluated. This aids to distinguish the appropriate sources of metals to the cattle and in identification of

120 intake and output route of metals which helps to formulate mitigation strategies. For the best of the knowledge,

121 the mass balance concept for the milk contaminated by the metal including soil as potential intake has not been

122 studied before.

123 Ranipet is an industrial hub in southern India mainly known for its leather production, contributing $37 \%$

124 of country's export leather and finished products. There are other medium to small-scale industries in Ranipet,

125 mostly engaged in chemical, leather and tool making. Several publications reported about the widespread pollution

126 in water and soil due to the effluents and waste discharged from various industries in the surrounding waterbodies

127 (Srinivasa Gowd and Govil 2008). The present study area, Puliyanthangal Lake is one among the water bodies

128 situated in this area, receiving partially treated and untreated wastes from near-by industries and untreated

129 domestic wastes from the surrounding villages (Government of India, Ministry of MSME 2016; Thangarajan,

130 1999). Recent publication reported about the multiple metal enrichment in the soil and vegetation in the lake bed

131 and suspected that the milk of the cattle raised from the lake area may also have elevated level of metals (Sai

132 Chaithanya et al. 2021).

133 Based on that finding, the present study attempted to investigate the metal concentrations in the milk of

134 the cattle grazing in the lake bed. Human health risk has been assessed among adults and children who are

135 consuming milk. The mass balance approach has been adopted to perceive the most important intake and output

136 route for individual metals along with their percentage of accumulation in the cattle. 


\section{Materials and methods}

\section{Study area}

139 Ranipet industrial area spreads over $54 \mathrm{~km}^{2}$ and mushroomed with numerous tanneries, ceramics, pigments and

140 paints, pharmaceuticals, refractories, chemicals and industrial hubs (Tamma Rao et al. 2013). This is also the

141 location of Tamil Nadu Chromate and Chemicals Limited (TCCL); which is reported to have 0.15 million tons of

142 open dumps of Chromium wastes for decades; contaminating groundwater and soil in its vicinity to considerable

143 extent (TNPCB 2010). This site is considered to be one among the world's worst ten toxic threat (Blacksmith

144 institute 2013). Most of the small-scale industries in this area discharges partially treated and untreated wastes

145 into the surrounding water bodies such as Palar river, Puliyanthangal Lake, Vanapadi Lake, Narasingapuram Lake,

146 Puliyangannu Lake and Chettithangal Lake (Srinivasa Gowd and Govil 2008). Moreover, these lakes are shallow

147 and grazing by cattle has been observed on the unsubmerged parts of the lake beds throughout the year. The study

148 area, Puliyanthangal Lake (Fig. 1) is one among these lakes (Latitude $12^{\circ} 57^{\prime} 53.12^{\prime \prime}$; Longitude $79^{\circ} 17^{\prime} 36.99^{\prime \prime}$ )

149 located in Ranipet industrial area of Tamil Nadu. The lake area is of 21.6 ha and the submerged area fluctuating

150 from 0.80 ha (pre-monsoon) to 14.70 ha (post monsoon). Topographically, this area is covered by metamorphic

151 rocks; mostly gneiss and granite of Archean age. The unsubmerged part of the lake area is used as grazing ground

152 for cattle from the surrounding villages. It has been observed that the cows are the only cattle grazing and ingesting

153 lake water throughout the year in the study area.

\section{Collection of samples}

155 The present study was conducted to identify the metal contamination transfer from forage, soil and water to the

156 cattle reared in Puliyanthangal Lake. Also, the transfer of metals through food chain by consumption of milk by

157 adults and children was evaluated. Hence a systematic procedure was adopted in selection of various types of

158 samples. The methodology adopted is shown in the Fig. 2

All the samples were collected during the month of April, 2018. Ten healthy cows among the cattle reared in the study area were randomly selected to maintain uniformity in sampling and their respective milk,

161 urine and dung were collected. All the samples were collected with the consent of the owners to use in this study. The cattle were never stimulated or forced to excrete dung and urine. 
165 Then they were filtered through Millipore $0.45 \mu \mathrm{m}$ filter paper; acidified to $\mathrm{pH}$ less than 2 and stored in refrigerator until analysis at $4^{0} \mathrm{C}$ (Miclean et al. 2019). (common wireweed) and Eclipta prostrata (false daisy). All three types of plants are being consumed by the cattle were considered in this study. As per the area preliminary investigation, the daily weighted consumption by cattle was considered as 80:10:10 for Cynodon dactylon, Sida acuta, and Eclipta prostrata respectively. The plant samples (n=7; P-1 to P-7) were collected along with their root from the accessible parts of lake area where cattle grazing was observed. Among them, three samples were from Cynodon dactylon and two samples each from Sida acuta and Eclipta prostrata. The samples were taken out carefully and brought back to laboratory in air-tight zip lock pouches. They were cleaned properly with double distilled water; air dried and oven dried at $50{ }^{\circ} \mathrm{C}$ until they obtained constant weight; crushed by using mortar and pestle and stored in a vacuum desiccator until analysis (Almeida et al. 2004). The soil samples ( $n=14$; S-1 to S-14) were considered from the study Chaithanya et al.

177 (2021) as the samples were collected in the similar time frame from the same study area.

Milk samples (n=10; M-1 to M-10) were collected in triplicates in the acid pre-washed sterile plastic containers during evening milking hours. Then, samples were transferred to laboratory in ice box and immediately digested for metal analysis on the same day. Urine samples (n=10; U-1 to U-10) were collected in triplicates;

181 directly upon excretion from the cattle to prevent contamination from the contact of the ground surface. All the samples were packed separately in acid pre-washed sterile plastic containers and transferred to laboratory in ice

183 box and immediately digested for metal analysis on the same day. Similarly, the cattle-dung (CD) samples (n=10;

184 CD-1 to CD-10) were collected directly upon excretion into sterile containers. After transferring, the samples 185 were air dried; then they were crushed by using mortar and pestle and stored in vacuum desiccator until analysis 186 (Zhang et al. 2012).

\section{Microwave digestion}

188 All the samples were digested in Multiwave Pro 24-HVT50 (Make-Anton Paar). The milk and urine samples were subjected to digestion by accurately transferring $1 \mathrm{ml}$ of sample to Teflon vessels by using $8 \mathrm{~mL}$ Nitric acid $65 \%$

190 and $2 \mathrm{~mL}$ Hydrogen peroxide 30\% (Miclean et al. 2019). For cattle-dung samples, $0.5 \mathrm{~g}$ of sample with same mixture was considered (Zhang et al. 2012). For plant samples, $0.5 \mathrm{~g}$ of sample with $6 \mathrm{ml}$ Hydrochloric acid and

192 2ml Nitric acid were used as aqua-regia (Almeida et al. 2004). Blanks were also subjected to same conditions for quality control. After digestion, Teflon vessels were carefully opened under fume hood, transferred to vacuum 
194 filtration unit, filtered through Millipore $0.45 \mu \mathrm{m}$ filter paper; filtered samples were refrigerated at $4^{\circ} \mathrm{C}$ in sterile

195 sample containers prior to analysis (Mohammed et al. 2017).

\section{Analysis and quality control}

197 In the present study eight metals ( $\mathrm{Al}, \mathrm{Cd}, \mathrm{Cr}, \mathrm{Cu}, \mathrm{Fe}, \mathrm{Mn}, \mathrm{Pb}$ and $\mathrm{Zn}$ ) have been selected for water, plant, milk,

198 urine and dung samples analysis. All the metals were analysed by inductively-coupled plasma optical emission spectrometry (ICPOES, Model Avio-200, Perkin Elmer) (Antoniadis et al. 2019). The operational parameters of ICPOES are mentioned in the Supplementary Table S1. The multi-elemental standards of Perkin Elmer were utilized for obtaining calibration; by serial dilution of $100 \mathrm{mg} / \mathrm{L}$. For quality control purpose, all the samples were measured in triplicates. Two method blanks were used for a batch of 24 samples and the analysis was repeated for $15 \%$ of the samples. The standard deviation for the measured analytes and samples were less than $10 \%$. The variations in the concentration of repeat samples were below 10\%. Also, the Relative Standard Deviations (RSD) of each set of replicate samples were below $15 \%$ for all the metals analysed.

207 The owners of the cattle (CO) grazing in the study area are from the surrounding Puliyanthangal and Periyanthangal villages. The information regarding the average self-consumption of milk by the owners (children and adult) and total milk yield per day from all the cattle were collected to estimate the amount of milk directed for sale.

\section{Market survey to estimate average daily intake of milk buyers}

212 To identify the average daily intake of milk consumption among children and adults, market surveys were

213 conducted among ten milk buyers (MB) in the study area. The data regarding consumption patterns and average

214 daily intake of milk along with the number of adults and children in their families were collected.

\section{Survey to estimate average daily intake, milk yield and excretion of cattle from cattle herds and owners}

216 To identify the average daily dietary intakes and average daily excretion details of the cattle, surveys were

217 conducted among the cow herds and owners of the cattle rearing in the study area. Details covering daily intake

218 of forage and water, total milk yield, urine and faecal excretion patterns of cattle ( $\mathrm{n}=10$; $\mathrm{C}-1$ to $\mathrm{C}-10)$ were asked personally the responses were considered for estimating them. 
221 The mass balance study was conducted to identify the daily average metal intake, excretion and respective bioaccumulations by the cattle. The mass balance study was carried out on the basis of following considerations:

1. The input information such as daily intake of water and forage by cattle and output information such as daily yield of milk, excretion of urine and dung were based on single time sampling.

2. The cattle daily ingestion rate of soil while grazing was considered from the literature (Healy 1972; Mayland et al. 1975).

3. The information for calculating mass balance equation was based on the average of randomly selected ten cattle among the total cattle grazing regularly in the study area.

4. The metabolism of cattle was considered to be constant; the parameters such as cattle intake, milk yield, quantity of urine and dung are constant throughout this period. Hence, mean intake and output were taken into the account in these calculations.

$$
\text { Metal }_{\text {input }}=\text { Metal }_{\text {output }}+\text { Metal }_{\text {accumulation }}
$$

Metal $_{\text {output }}$ was total output by cow through milk, dung and urine in $\mathrm{mg} / \mathrm{day} / \mathrm{cow} ; \mathrm{Metal}_{\text {accumulation }}$ into cattle was the difference between input and output in $\mathrm{mg} / \mathrm{day} / \mathrm{cow}$. The quantity of intake by water and forage; and the quantity of output by milk, dung and urine for ten cattle was estimated from the survey conducted among cattle herds and owners from the study area. The soil ingestion rate of cattle per day by grazing was considered from the literature.

\section{Risk determination}

243 The daily intake of metal considered to be chronic can be calculated by using the following equation

$$
\text { Chronic Daily Intake }(C D I)=C_{\text {metal }} D_{\text {milk intake }} / B_{\text {average weight }}
$$

Where, $\mathrm{C}$ is the metal concentration in the milk in $\mathrm{mg} / \mathrm{kg}$, D is the amount of milk consumed in $\mathrm{kg}$ and

246 B is the body weight in $\mathrm{kg}$ (Castro Gonzalez et al. 2017). Average Indian adult body weight was considered as 52 $247 \mathrm{~kg}$ as per Giri and Singh (2019) and $15 \mathrm{~kg}$ for children. The following risk assessment indices were considered 
248 for evaluating the associated health risk to humans by consumption of milk.

$250 \mathrm{HQ}$ is the ratio of chronic daily intake of a metal to its oral reference dose and calculated by using the following equation

$$
\mathrm{HQ}=C D I / R_{f} D
$$

254 for $\mathrm{Al}, \mathrm{Cd}, \mathrm{Cr}, \mathrm{Cu}, \mathrm{Fe}, \mathrm{Mn}, \mathrm{Pb}$ and $\mathrm{Zn}$ respectively. (Integrated Risk Information System (IRIS) 2015, Castro Gonzalez et al. 2017) The value of HQ greater than unity indicates probable harmful health effects for the exposed population.

The HI is the summation of individual HQ of studied metals. HI provides the collective potential risk of all the metals. The value of HI greater than unity indicates possible detrimental effect on human health.

$$
H I=\sum H Q_{i}
$$
considered (Castro Gonzalez et al. 2017).

The risk of cancer from consumption of milk from the study area can be calculated by using the following equation

$$
I L C R=\mathrm{CDI} \times \mathrm{SF}
$$
$(\mathrm{Cd}, \mathrm{Cr}$ and $\mathrm{Pb}$ ). The $\mathrm{SF}$ values for $\mathrm{Cd}, \mathrm{Cr}$ and $\mathrm{Pb}$ were $0.38,0.05$ and 0.0085 (Castro Gonzalez et al. 2017; Ukah et al. 2019). The ILCR can be considered as "acceptable" when ILCR is less than $1.0 \times 10^{-6}$ and it is "serious" when the value exceeds $10^{-4}$. 
273 Where, $I L C R_{i}$ is lifetime cancer risk for individual metal (Cr. Cd, and $\mathrm{Pb}$ ) and Cancer Risk total is the total

274 lifetime cancer risk for all the three metals.

\section{Statistical application}

To identify possible sources of contamination in the study area, Principal Component Analysis (PCA) was performed by using factor extraction by IBM SPSS Statistics 23. All graphs were plotted by using Origin Pro, 2017. Data handling and mean were calculated by using Microsoft Excel, 2010 (Giri and Singh 2020).

\section{Results and Discussion}

\section{Metal concentrations in the water, plant and soil samples}

The water samples collected from the lake showed significant concentrations of metals such as $\mathrm{Al}, \mathrm{Cr}, \mathrm{Fe}$ and $\mathrm{Mn}$ (Table 1). The metals in lake water samples were in the range of $0.04-2.86 \mathrm{mg} / \mathrm{L}$ for $\mathrm{Al}, 0.05-0.18 \mathrm{mg} / \mathrm{L} \mathrm{for}$ $\mathrm{Cd}, 0.84-6.73 \mathrm{mg} / \mathrm{L}$ for $\mathrm{Cr}, 0.01-0.78 \mathrm{mg} / \mathrm{L}$ for $\mathrm{Cu}, 0.31-1.70 \mathrm{mg} / \mathrm{L}$ for Fe, $0.23-1.84 \mathrm{mg} / \mathrm{L}$ for $\mathrm{Mn}$ and 0.20 $-0.66 \mathrm{mg} / \mathrm{L}$ for $\mathrm{Zn}$. The $\mathrm{Cr}$ was predominated in the water samples as its largest input to the lake water was due to the discharge of partially treated and untreated effluents from nearby tanneries (Srinivasa Gowd and Govil 2008). Also, as the lake receives runoff from nearby agricultural fields and domestic wastes from the surrounding villages, the lake water was contaminated to significant extent and it exceeded BIS (BIS 2012) limits of drinking water except for Zn. Further, the lake water being the primary source of drinking for the cattle reared in this region, the cattle intake metal contaminated water throughout their life time; increasing their probability of risk to metal accumulation.

The plant samples collected from the study area showed extreme concentrations of $\mathrm{Al}, \mathrm{Cr}, \mathrm{Fe}, \mathrm{Mn}$ and moderate concentrations of $\mathrm{Cu}, \mathrm{Pb}, \mathrm{Zn}$; their mean concentrations are shown in Table 1 . The metals in plant samples were in the range of $254.91-402.15 \mathrm{mg} / \mathrm{kg}$ for $\mathrm{Al}, 0.36-0.96 \mathrm{mg} / \mathrm{kg}$ for Cd, $97.92-198.97 \mathrm{mg} / \mathrm{kg}$ for $\mathrm{Cr}, 3.73-10.89 \mathrm{mg} / \mathrm{kg}$ for $\mathrm{Cu}, 232.25-1132.24 \mathrm{mg} / \mathrm{kg}$ for Fe, $17.34-48.38 \mathrm{mg} / \mathrm{kg}$ for Mn, $0.58-3.16 \mathrm{mg} / \mathrm{kg}$ for $\mathrm{Pb}$ and $5.77-25.68 \mathrm{mg} / \mathrm{kg}$ for $\mathrm{Zn}$. The huge concentrations of metals observed in the plant samples were due to the transfer of metals from the lake bed sediments. Puliyanthangal Lake was reported for its chromium 
contamination in the sediments (Srinivasa Gowd and Govil 2008; Mandal et al. 2011) ; but our previous study on

298 the lake-bed sediments indicated significant anthropogenic multi-metal enrichment. Further, these metals were

299 present in bio-available forms; hence aiding in accumulation of metals in the vegetation growing on the lake bed

300 (Sai Chaithanya et al. 2021). Thus, the cattle reared locally in the study area ingests contaminated vegetation on

301 daily basis; opening the gateway for these metals into the food chain. The soil samples were considered from the study Chaithanya et al. (2021); mean metal concentration of soil samples is shown in Table 1.

\section{Metal concentrations in the milk samples}

304 The metal analysis of milk samples collected showed variations in the metals analysed (Table 1); metals like Al,

305 Fe and Zn showed higher concentrations than others. The metals in milk samples were in the range of $0.62-19.49$

$306 \mathrm{mg} / \mathrm{L}$ for $\mathrm{Al}, 0.006-0.014 \mathrm{mg} / \mathrm{L}$ for $\mathrm{Cd}, 0.06-0.30 \mathrm{mg} / \mathrm{L}$ for $\mathrm{Cr}, 0.026-0.044 \mathrm{mg} / \mathrm{L}$ for $\mathrm{Cu}, 0.39-8.31 \mathrm{for} F e$,

$3070.024-0.282 \mathrm{mg} / \mathrm{L}$ for $\mathrm{Mn}, 0.05-0.39 \mathrm{mg} / \mathrm{L}$ for $\mathrm{Pb}$ and $10.02-36.25 \mathrm{mg} / \mathrm{L}$ for $\mathrm{Zn}$. The Indian standards for

308 metal contaminants in milk are only available for $\mathrm{Pb}$; the metal concentrations observed for $\mathrm{Pb}$ was higher than

309 the permissible limit $(0.02 \mathrm{mg} / \mathrm{L})$ in most of the samples (Food Safety and Standards Regulations 2011).

\section{Metal concentrations in the urine and cattle-dung samples}

311 To understand the extent of exposure of cattle by grazing forage and by ingestion of lake water, metal 312 concentrations of their urine and dung samples was determined (Table 1). The metals in urine samples were in the 313 range of $1.53-13.32 \mathrm{mg} / \mathrm{L}$ for $\mathrm{Al}, 0.005-0.012 \mathrm{mg} / \mathrm{L}$ for $\mathrm{Cd}, 0.08-0.31 \mathrm{mg} / \mathrm{L}$ for $\mathrm{Cr}, 0.006-0.076 \mathrm{mg} / \mathrm{L}$ for $314 \mathrm{Cu}, 0.38-10.83 \mathrm{mg} / \mathrm{L}$ for $\mathrm{Fe}, 0.019-0.605 \mathrm{mg} / \mathrm{L}$ for $\mathrm{Mn}, 0.06-0.26 \mathrm{mg} / \mathrm{L}$ for $\mathrm{Pb}$ and $0.04-1.06 \mathrm{mg} / \mathrm{L}$ for $\mathrm{Zn}$.

315 The highest metal concentrations observed was $\mathrm{Al}$ with $13.2 \mathrm{mg} / \mathrm{L}$ and $\mathrm{Fe}$ with $10.83 \mathrm{mg} / \mathrm{L}$. The Cd was below 316 detection level in most of the samples with $0.012 \mathrm{mg} / \mathrm{L}$ as maximum concentration. The metals in cattle-dung 317 samples were in the range of $1079.07-5536.25 \mathrm{mg} / \mathrm{kg}$ for Al, $0.12-0.84 \mathrm{mg} / \mathrm{kg}$ for Cd, $16.48-420.62 \mathrm{mg} / \mathrm{kg}$ 318 for $\mathrm{Cr}, 29.31-99.48 \mathrm{mg} / \mathrm{kg}$ for $\mathrm{Cu}, 1244.11-4198.80 \mathrm{mg} / \mathrm{kg}$ for Fe, $142.61-263.07 \mathrm{mg} / \mathrm{kg}$ for Mn, $5.62-12.67$ $319 \mathrm{mg} / \mathrm{kg}$ for $\mathrm{Pb}$ and $62.35-119.82 \mathrm{mg} / \mathrm{kg}$ for $\mathrm{Zn}$. Chromium was found as high as $420.62 \mathrm{mg} / \mathrm{kg}$, highest 320 concentrations of $\mathrm{Cu}, \mathrm{Mn}$ and $\mathrm{Pb}$ were $99.48,263.07$ and $12.67 \mathrm{mg} / \mathrm{kg}$. As cattle were observed to be in lake for 321 most of the time in a day, the excretion of dung on lake bed can be considered as secondary source of metal contamination. 
324 The cattle from Puliyanthangal village and Periyanthangal village were usually fed on the pastures and water of

325 Puliyanthangal Lake. Total number of cattle which are grazing regularly in the study area were counted as ninety-

326 one from thirty-eight owners. The self-consumption of milk by these thirty-eight families was calculated and 327 averaged. Apart from this, the total milk yield from the ninety-one cattle were estimated to be $339 \mathrm{~L}$ per day with 328 an average yield of $3.72 \mathrm{~L}$ of milk per day per cow.

329 The results from the survey showed that, the average daily consumption of milk per family was around

$330 \quad 0.56 \mathrm{~L}$ (Table 2). As the total milk yield from the cattle were estimated to be $339 \mathrm{~L}$ per day, thirty-eight families

331 of owners consume $21.2 \mathrm{~L}$ of milk per day. The remaining $317.8 \mathrm{~L}$ of milk was sold to the houses in the

332 surrounding villages. The survey results showed that $60 \%$ of adults were consuming the milk whereas in case of

333 children, it was $100 \%$. Hence children in the study area have higher probability of contaminated milk intake than

334 adults.

Market surveys to estimate average daily intake of milk by consumers

336 Market survey was conducted to understand the dietary habits and consumption patterns among the local

337 consumers of this milk from ten families (Table 3). The daily intake of milk by adults and children were calculated

338 separately by measuring the volumes of their respective containers used for the consumption of milk on daily

339 basis. The mean volume was considered and applied in estimation of CDI. It was observed that the daily intake

340 of adult and child was $206.5 \mathrm{~mL}$ and $145 \mathrm{~mL}$ per day respectively.

341 Surveys to estimate average daily intake, milk yield and excretion of cattle from cattle herds and

342 owners

343 The survey was conducted among the cattle herds and owners to identify the average daily intake of feed and

344 water of cattle along with their average daily milk yield. Also, the data regarding average daily excrements of 345 urine and dung were collected. The intake of forage by cattle was in the range of $20-30 \mathrm{~kg} / \mathrm{day}$ whereas the 346 water intake was $30-40 \mathrm{~L}$ in a day (Table 4). The yield of milk from a single one ranged from $2-6 \mathrm{~L}$ per day.

347 Also, the daily excrements from cattle in the form of urine and dung were $5-8 \mathrm{~L}$ per day and $6-10 \mathrm{~kg}$ per day 348 respectively. Hence, for the mass balance study, the mean of these values collected from ten cattle were utilized.

\section{Mass balance}

350 To investigate the primary source and sink of metals in the cattle, mass balance study was conducted by calculating

351 total metal intakes and outputs. The difference between the input and output provides insights about the 

ground level. Hence, ingestion of soil while grazing was considered as one of the input of metals to the cattle. The soil ingestion rate was estimated to be in the range of 0.1 to $1.5 \mathrm{~kg} / \mathrm{animal}$ per day; with a median value of 0.5 $\mathrm{kg} / \mathrm{animal}$ per day. Hence, this value was adopted for calculating soil ingestion rate of cattle per day in the mass balance study (Healy 1972; Mayland et al. 1975). Also, the mean metal concentrations of soil from the study area were considered from Chaithanya et al. (2021).

The Fig. 3 shows the mass balance of metals in percentages and concentrations of input and output. The highest input of all the metals except $\mathrm{Al}$ to the cattle were due to the grazing of contaminated forage. The ingestion of soil while grazing is the major source of Al. The estimated percentages of accumulation of metals in cattle were in the order of $\mathrm{Cd}>\mathrm{Cr}>\mathrm{Fe}>\mathrm{Al}>\mathrm{Pb}>\mathrm{Mn}>\mathrm{Zn}>\mathrm{Cu}$. This can be further supported by the identified concentrations of $\mathrm{Al}, \mathrm{Cr}$,

$362 \mathrm{Fe}, \mathrm{Mn}$ and $\mathrm{Zn}$ accumulated in the tail switch hair of these cattle (Supplementary Table S2). Also, organs like liver and kidneys were prone to metal bio-accumulations, detail insight regarding bio-accumulation capacities of different metals can be obtained by considering these samples for further studies (Miranda et al. 2009). leaving through excretion through dung were significantly higher than other metals. It indicates substantial concentrations of these metals in their consumed feed (Zhang et al. 2012). The metals excreted through urine were considerably less; even though the estimated concentrations by mass balance approach showed ample amount of $\mathrm{Al}$ and $\mathrm{Fe}$, the overall percentage of these metals leaving through urine were negligible. The percentages of $\mathrm{Pb}$ and $\mathrm{Zn}$ leaving through milk were higher than other metals. Thus, $\mathrm{Pb}$ and $\mathrm{Zn}$ pave their way into the food chain from contaminated forage and water; which reflected in the substantial HQ and HI values.

\section{Risk assessment of metals due to milk consumption}

373 To identify the risk associated to the human health by consumption of milk from the study area, health risk 374 assessment was performed. Chronic daily intake (CDI), hazard quotient (HQ), hazard index (HI) and incremental

375 lifetime cancer risk (ILCR) was evaluated. The mean CDI values of metals for adult and child through the milk 376 consumption are mentioned in Table 5. Moreover, the mean CDI values were compared with the provisional 377 tolerable daily intake (PTDI) values suggested by Food and agriculture organisation of the United States (FAO) 378 and World Health Organisation (WHO); mentioned in Table 4 (JECFA 2003). The mean CDI values for adults 379 and children were lesser than the PTDI values. 
381 For adults, the individual metals may not pose any considerable risk as none of the metals has HQ value greater

382 than unity. However, for children, $\mathrm{Pb}$ and $\mathrm{Zn}$ showed few values greater than 1, indicating significant risk by these metals through milk consumption. The HI provides the overall risk by combining the effects of all the metals; for adults, HI values ranged from 0.23 to 0.76 with mean of 0.54 (Table 6). For children, HI values ranged from 0.55 to 1.85 with mean of 1.31 ; which is higher than 1 , indicating significant risk to them. The $\mathrm{Pb}$ and $\mathrm{Zn}$ are the highest contributors with the $\mathrm{HI}$ values of 1.03 and 1.16 respectively. The permissible limit for $\mathrm{Pb}$ in milk is limited to $0.2 \mathrm{ppm}$ according to Food Safety and Standards Regulations (2011). The children under six years are more vulnerable to the adverse effects even at lower threshold levels than adults; $\mathrm{Pb}$ contamination by food can cause neurological disorders and can be carcinogenic. Even though the $\mathrm{Zn}$ is not as toxic as $\mathrm{Pb}$, excess $\mathrm{Zn}$ intake can cause nausea, vomiting, diarrhoea and fever. Hence, the children are more likely to be affected than adults by consuming the cattle milk from the study area.

The ILCR values of $\mathrm{Cd}$ and $\mathrm{Cr}$ were above $10^{-4}$ for consumption of milk in both adults and children (Fig.

393 4). The ILCR levels were highest in children $(\mathrm{Cd}=0.0020$ and $\mathrm{Cr}=0.0014)$ than in adults $(\mathrm{Cd}=0.0008$ and $\mathrm{Cr}$

$394=0.0006)$. Hence, there is considerable cancer risk for the adults and children by consuming the cattle milk from the study area. Also, the combined cancer risk due to $\mathrm{Cd}, \mathrm{Cr}$ and $\mathrm{Pb}$ indicated that there is significant risk for both adults and children. The $\mathrm{Cd}$ can cause lung and renal cancers in humans; $\mathrm{Cr}$ present in $\mathrm{Cr}(+6)$ form (chromate) can be toxic and carcinogenic. The $\mathrm{Cr}$ can cause lung, gastrointestinal and breast cancers. Moreover, when children are habituated for daily intake of contaminated food; leads to the progressive accumulation of metals in the organs, can lead to the health complications when they become older (Castro Gonzalez et al. 2017). Hence it is advised to quit the consumption of milk from the cattle rearing in the study area.

\section{Estimating the number of people potentially at risk from drinking metal contaminated milk}

To estimate the number of people consuming the metal contaminated milk from the cattle reared in the study area, the cattle owners were identified and their mean self-consumption of milk per family per day was estimated to be $0.56 \mathrm{~L} / \mathrm{day}$. Also, the total milk yield from the ninety-one cattle per day was estimated to be 339 L/day. Hence, $21 \mathrm{~L}$ of milk per day was self-consumed by the cattle-owners. The rest of the remaining milk i.e., $318 \mathrm{~L} /$ day was sold to the consumers. From the market survey conducted among the consumers of the milk, the average daily intake of milk per adult and child was estimated to be $206.5 \mathrm{~mL}$ and $145 \mathrm{~mL}$ per day respectively. Also, from the surveys conducted among thirty-eight families, it was approximated that the number of children 
410 the number of adults and children at potential risk from consuming this metal contaminated milk was

411 approximated to be 1279 adults and 531 children. The calculation regarding this estimation is mentioned under

412 the section 'Risk estimation'; refer to Supplementary Information.

\section{Source identification}

414 To identify sources of the metals identified in milk samples of the study area, multivariate Principal Component

415 Analysis (PCA) was applied by using SPSS. The VARIMAX rotation along with Kaiser Normalization was used

416 to normalise the data. The PCA reduced number of variables to two principal components (PCs) (Table 7) which

417 explained $79.53 \%$ of data variance. The first principal component contributed $40.87 \%$ of total variance influenced

418 by metals such as $\mathrm{Al}, \mathrm{Cr}$ and $\mathrm{Fe}$. The presence of $\mathrm{Al}$ and $\mathrm{Fe}$ can be of natural origin as both are main components

419 of rock forming minerals (Lin et al. 2016). The anthropogenic sources of Fe in the study area are unknown. The

420 sources of $\mathrm{Cr}$ can be anthropogenic as the study area is mushroomed with tanneries; hence their effluent discharges

421 can be the only source (Srinivasa Gowd and Govil 2008). Hence the first principal component is combination of

422 both natural and anthropogenic sources.

423 The second principal component contributed $38.66 \%$ of variance influenced by $\mathrm{Cd}, \mathrm{Mn}$ and $\mathrm{Pb}$. The $\mathrm{Cd}$

424 can be due to the agricultural activities surrounding the study area. The presence of Mn can be due ceramic

425 industrial activities in the vicinity of lake as Mn is widely used in ceramic industries. Also, there is a possibility

426 of $\mathrm{Mn}$ and $\mathrm{Zn}$ enrichment from receiving runoff during storms from near-by agricultural fields, where they can be

427 used as fertilizers. The possible source for $\mathrm{Pb}$ in the study area can be possibly from pigments and paint industrial

428 activities. The presence of $\mathrm{Pb}$ and $\mathrm{Zn}$ can also be due to the vehicular activities of the area. Hence, the second

429 principal component seems to be associated with anthropogenic input.

\section{Conclusions}

431 1. The mass balanced study reveals that the major source of the metals is from grazing. Hence, grazing of the contaminated forage needs to be controlled and alternative feed can be provided for the cattle.

2. Soil is the most important route for the Al due to its elevated concentration. This indicates that soil cannot be overlooked as major source for ingestion when the soil concentration is high.

3. The milk of the cattle grazing in the study area is having elevated level of metals specifically $\mathrm{Al}, \mathrm{Fe}, \mathrm{Pb}$ and $\mathrm{Zn}$. The Ranipet industrial area has total surface water of 138 ha which is mostly shallow and being 
used for similar purposes. Considering the combined health risk associated with the contaminated milk produced in this area will be alarmingly high, mostly in the children.

4. The milk produced is also sold among the floating customers which makes the situation more critical and difficult to estimate.

5. The dung samples have elevated concentrations of $\mathrm{Al}, \mathrm{Cr}, \mathrm{Fe}, \mathrm{Mn}$ and $\mathrm{Zn}$ which can act as secondary sources of contamination as these cattle were observed to be in the lake area for most of the day time. As cow dung is the major sink of metals, the burning of cow dung cakes for domestic purposes may further lead to indoor air pollution (Pal et al. 2007).

6. The major fraction of the metals like $\mathrm{Al}, \mathrm{Cd}, \mathrm{Cr}$, and $\mathrm{Fe}$ are retaining in the cattle which was confirmed from the analysis of the tail-switch hair samples from the cattle (Supplementary Table S2). This indicate that the cattle are severely exposed to metal toxicity. Apart from that the human health risk associated with the consumption of cattle meat also needs to be evaluated.

7. Finally, most of the cattle reared within the industrial areas graze in the shallow basins/waterbodies, due to the unavailability of grazing lands. These areas are being used as unauthorized sites for the waste/effluent disposal and are most susceptible to metal contamination. Hence the cattle milk and meat can be a potential source of metal contamination in the food chain which need to be emphasized with detail monitoring and integrate into policy implication.

\section{References}

455 Al Osman M, Yang F, Massey IY (2019) Exposure routes and health effects of heavy metals on children. Biometals 32(4):563-73. https://doi.org/10.1007/s10534-019-00193-5.

Almeida CM, Mucha AP, Vasconcelos MT (2004) Influence of the sea rush Juncus maritimus on metal concentration and speciation in estuarine sediment colonized by the plant. Environmental science \& technology 38(11):3112-8. https://doi.org/10.1021/es049932j.

Antoniadis V, Golia EE, Liu YT, Wang SL, Shaheen SM, Rinklebe J (2019) Soil and maize contamination by trace elements and associated health risk assessment in the industrial area of Volos, Greece. Environment international 124:79-88. 10.1016/j.envint.2018.12.053

464 Blacksmith Institute (2013) The World's Worst 2013: The Top Ten Toxic Threats Cleanup, Progress, and 465 Ongoing Challenges Table 19. 
Boudebbouz A, Boudalia S, Bousbia A, Habila S, Boussadia MI, Gueroui Y (2020) Heavy metals levels in raw cow milk and health risk assessment across the globe: A systematic review. Science of The Total Environment 141830. https://doi.org/10.1016/j.scitotenv.2020.141830.

Castro Gonzalez NP, Moreno-Rojas R, Calderón Sánchez F, Moreno Ortega A, Juarez Meneses M (2017) Assessment risk to children's health due to consumption of cow's milk in polluted areas in Puebla and Tlaxcala, Mexico. Food Additives \& Contaminants: Part B 10(3):200-7. $\underline{10.1080 / 19393210.2017 .1316320 .}$

Healy WB (1972) Ingested soil and animal nutrition. In Proceedings of the New Zealand Grassland Association (pp. 84-90).

Integrated Risk Information System (IRIS) (2015) http://cfpub.epa.gov/ncea/iris/ compare.cfm.

Iqbal Z, Abbas F, Ibrahim M, Qureshi TI, Gul M, Mahmood A (2020) Human health risk assessment of heavy

Miranda M, Benedito JL, Blanco-Penedo I, López-Lamas C, Merino A, López-Alonso M (2009) Metal accumulation in cattle raised in a serpentine-soil area: relationship between metal concentrations in soil, metals in raw milk of buffalo feeding at wastewater-irrigated agricultural farms in Pakistan. Environmental Science and Pollution Research 27(23):29567-79. https://doi.org/10.1007/s11356-02009256-4.

JECFA (2003) Summary and conclusions of the 61st Meeting of the Joint FAO/ WHO expert committee on food additives (JECFA). JECFA/61/ SC; Rome, Italy.

Licata P, Di Bella G, Potortì AG, Lo Turco V, Salvo A, Dugo GM (2012) Determination of trace elements in goat and ovine milk from Calabria (Italy) by ICP-AES. Food Additives and Contaminants: Part B 5(4):26871. https://doi.org/10.1080/19393210.2012.705335.

Lin Q, Liu E, Zhang E, Li K, Shen J (2016) Spatial distribution, contamination and ecological risk assessment of heavy metals in surface sediments of Erhai Lake, a large eutrophic plateau lake in southwest China. Catena 145:193-203. https://doi.org/10.1016/j.catena.2016.06.003.

Mayland HF, Florence A, Rosenau RC, Lazar VA (1975) Soil ingestion by cattle on semiarid range as reflected by titanium analysis of feces. Journal of range management 28(6):448-52.

Miclean M, Cadar O, Levei EA, Roman R, Ozunu A, Levei L (2019) Metal (Pb, Cu, Cd, and Zn) transfer along food chain and health risk assessment through raw milk consumption from free-range cows. International journal of environmental research and public health 16(21):4064. https://doi.org/10.3390/ijerph16214064. forage and animal tissues. Journal of Trace Elements in Medicine and Biology 23(3):231-8. https://doi.org/10.1016/j.jtemb.2009.03.004. 
Mohammed E, Mohammed T, Mohammed A (2017) Optimization of an acid digestion procedure for the determination of $\mathrm{Hg}, \mathrm{As}, \mathrm{Sb}, \mathrm{Pb}$ and $\mathrm{Cd}$ in fish muscle tissue. MethodsX 4:513-23. https://doi.org/10.1016/j.mex.2017.11.006.

Pal A, Nayak B, Das B, Hossain MA, Ahamed S, Chakraborti D (2007) Additional danger of arsenic exposure through inhalation from burning of cow dung cakes laced with arsenic as a fuel in arsenic affected villages in Ganga-Meghna-Brahmaputra plain. Journal of Environmental Monitoring 9(10):1067-70. https://doi.org/10.1039/b709339j.

Pilarczyk R, Wójcik J, Czerniak P, Sablik P, Pilarczyk B, Tomza-Marciniak A (2013) Concentrations of toxic heavy metals and trace elements in raw milk of Simmental and Holstein-Friesian cows from organic farm. Environmental monitoring and assessment 185(10):8383-92. https://doi.org/10.1007/s10661-0133180-9.

Pšenková M, Toman R, Tančin V (2020) Concentrations of toxic metals and essential elements in raw cow milk from areas with potentially undisturbed and highly disturbed environment in Slovakia. Environmental Science and Pollution Research 27:26763-72. https://doi.org/10.1007/s11356-020-09093-5.

Raghu V (2015) Study of dung, urine, and milk of selected grazing animals as bioindicators in environmental geoscience - a case study from Mangampeta barite mining area, Kadapa District, Andhra Pradesh, India. Environmental monitoring and assessment 187(1):1-0. https://doi.org/10.1007/s10661-014-4080-3.

Rao GT, Rao VG, Ranganathan K (2013) Hydrogeochemistry and groundwater quality assessment of Ranipet industrial area, Tamil Nadu, India. Journal of Earth System Science 122(3):855-67. https://doi.org/10.1007/s12040-013-0295-X.

Sai Chaithanya M, Das B, Vidya R (2021) Assessment of metals pollution and subsequent ecological risk in water, sediments and vegetation from a shallow lake: a case study from Ranipet industrial town, Tamil Nadu, India. International Journal of Environmental Analytical Chemistry 1-8. https://doi.org/10.1080/03067319.2021.1882449.

Scheuplein R, Charnley G, Dourson M (2002) Differential sensitivity of children and adults to chemical toxicity: I. Biological basis. Regulatory Toxicology and Pharmacology 35(3):429-47. https://doi.org/10.1006/rtph.2002.1558.

Thangarajan M (1999) Modeling pollutant migration in the upper Palar river basin, Tamil Nadu, India. Environmental Geology 38(3):209-22.

TNPCB (2010) Revised Action Plan for Critically Polluted Area, Ranipet.

Ukah BU, Egbueri JC, Unigwe CO, Ubido OE (2019) Extent of heavy metals pollution and health risk assessment of groundwater in a densely populated industrial area, Lagos, Nigeria. International Journal of Energy and Water Resources 3(4):291-303. https://doi.org/10.1007/s42108-019-00039-3.

Yasotha A, Dabadé DS, Singh VP, Sivakumar T (2020) Risk assessment of heavy metals in milk from cows reared around industrial areas in India. Environmental Geochemistry and Health 1-7. https://doi.org/10.1007/s10653-020-00758-1.

Zhang F, Li Y, Yang M, Li W (2012) Content of heavy metals in animal feeds and manures from farms of different scales in northeast China. International journal of environmental research and public health 9(8):265868. https://doi.org/10.3390/ijerph9082658. 
543

544

545

546

547

548

549

550

551

552

553

554

555

556

557

558

559

560

561

562

563

564

565

566

567

568
Zhang G, Bai J, Xiao R, Zhao Q, Jia J, Cui B, Liu X (2017) Heavy metal fractions and ecological risk assessment in sediments from urban, rural and reclamation-affected rivers of the Pearl River Estuary, China. Chemosphere 184:278-88. https://doi.org/10.1016/j.chemosphere.2017.05.155.

Zhou X, Zheng N, Su C, Wang J, Soyeurt H (2019) Relationships between Pb, As, Cr, and Cd in individual cows' milk and milk composition and heavy metal contents in water, silage, and soil. Environmental Pollution 255:113322. https://doi.org/10.1016/j.envpol.2019.113322. 
570 Fig. 1 Location of Puliyanthangal lake

571 Fig. 2 Methodology flow chart

$572 \quad$ Fig. 3 Mass balance chart

573 Fig. 4 Incremental lifetime Cancer Risk (ILCR) in adults and children

\section{$574 \quad$ List of Tables}

575 Table 1 Mean metal concentrations in Lake water, forage, soil, cow milk, cow urine and cow-dung samples

576 (water, milk and urine values are in $\mathrm{mg} / \mathrm{L}$ whereas forage and dung values are in $\mathrm{mg} / \mathrm{kg}$ )

577 Table 2 Survey results of estimation of total milk yield and self-consumption patterns from cattle owners

578 Table 3 Market survey results of estimation of daily milk intake in child and adult from consumers

579 Table 4 Survey results of estimation of average daily intakes, excretions and milk yield of cattle from cow herds 580 and owners

581 Table 5 Chronic daily intake (CDI) of metals by consumption of milk from study area

582 Table 6 Hazard quotient (HQ) of metals by consumption of milk from study area

583 Table 7 Principal component analysis loadings for the metals in the milk samples 
Figures

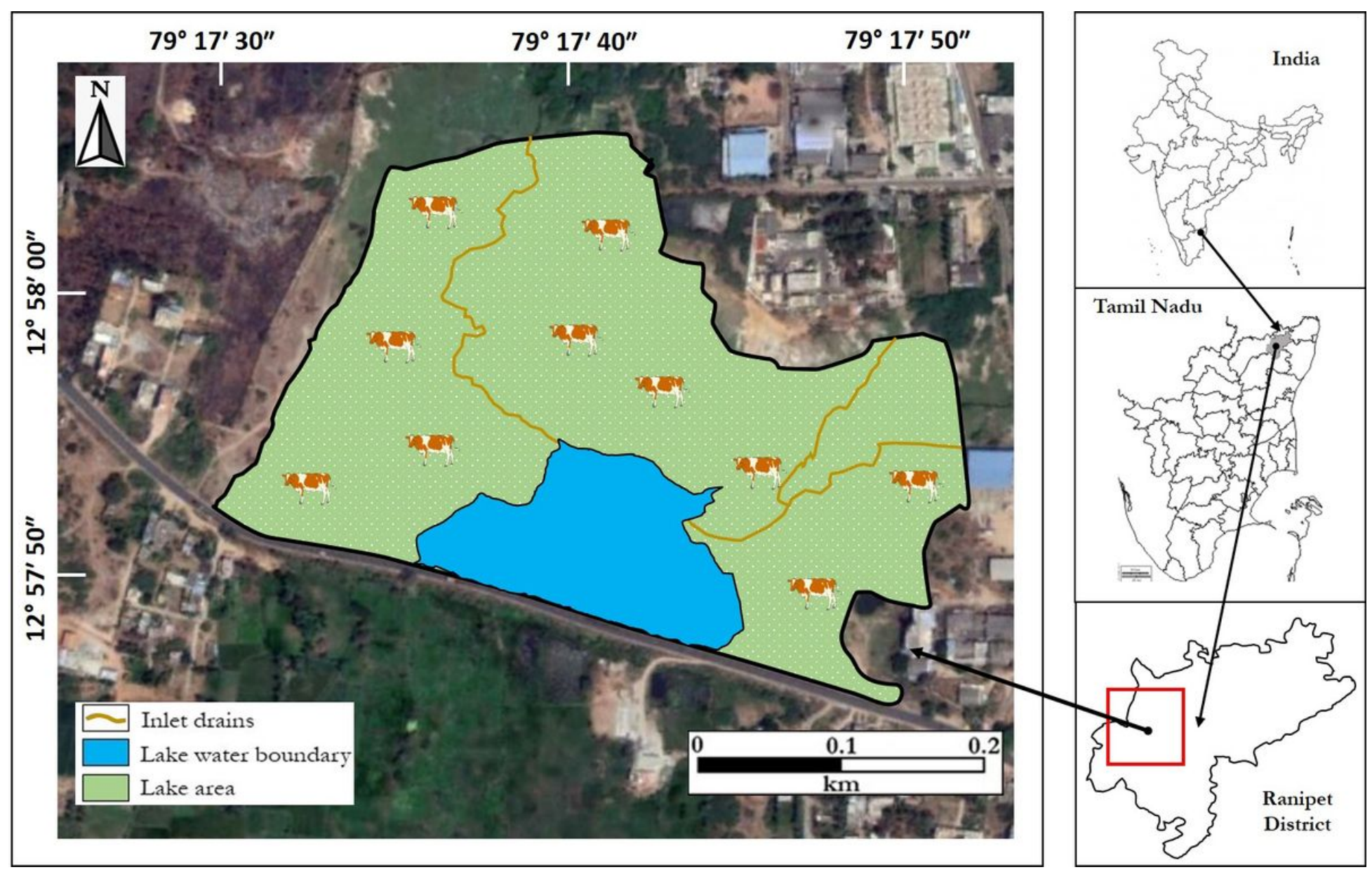

Figure 1

Location of Puliyanthangal lake 


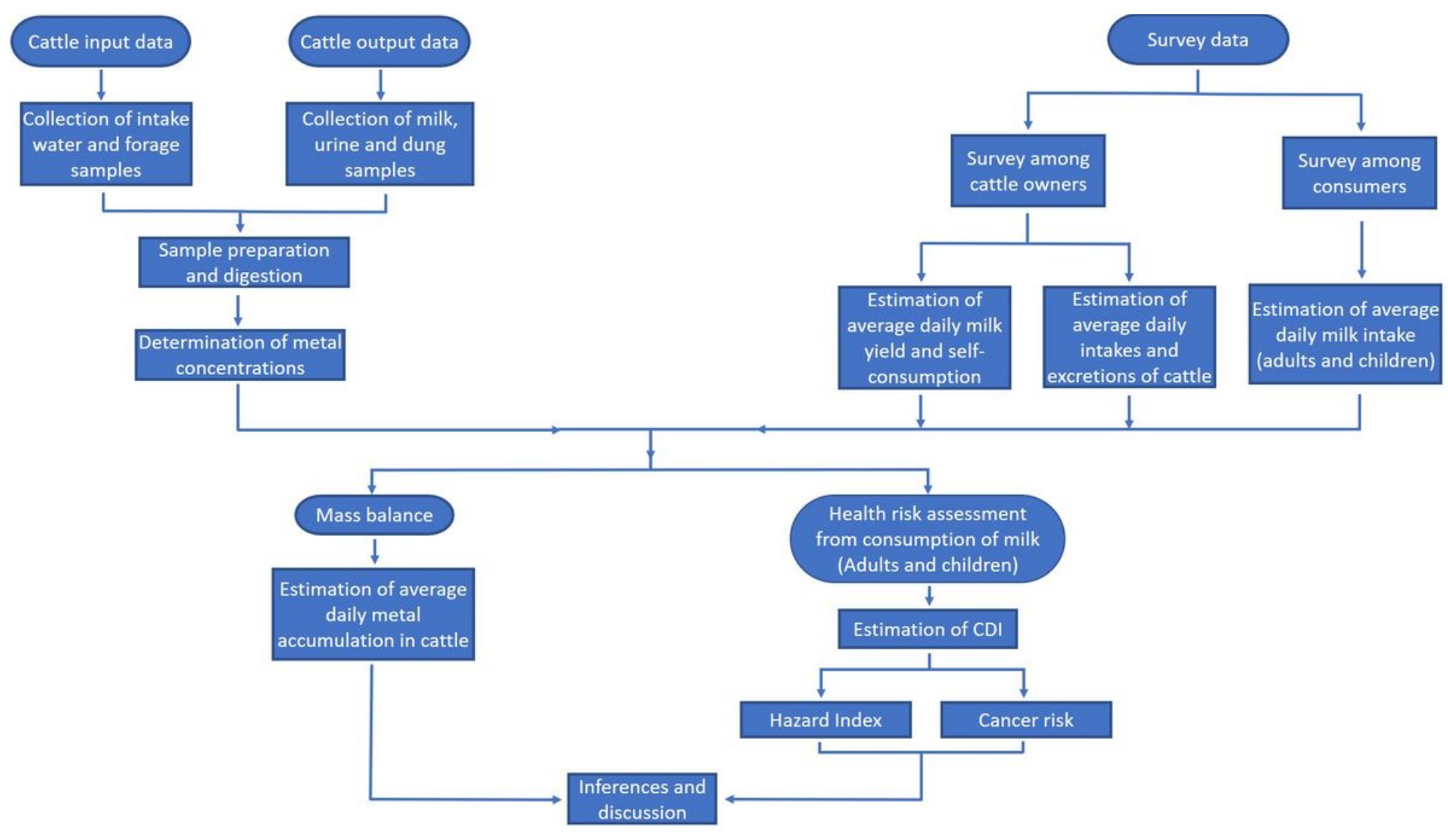

Figure 2

Methodology flow chart 


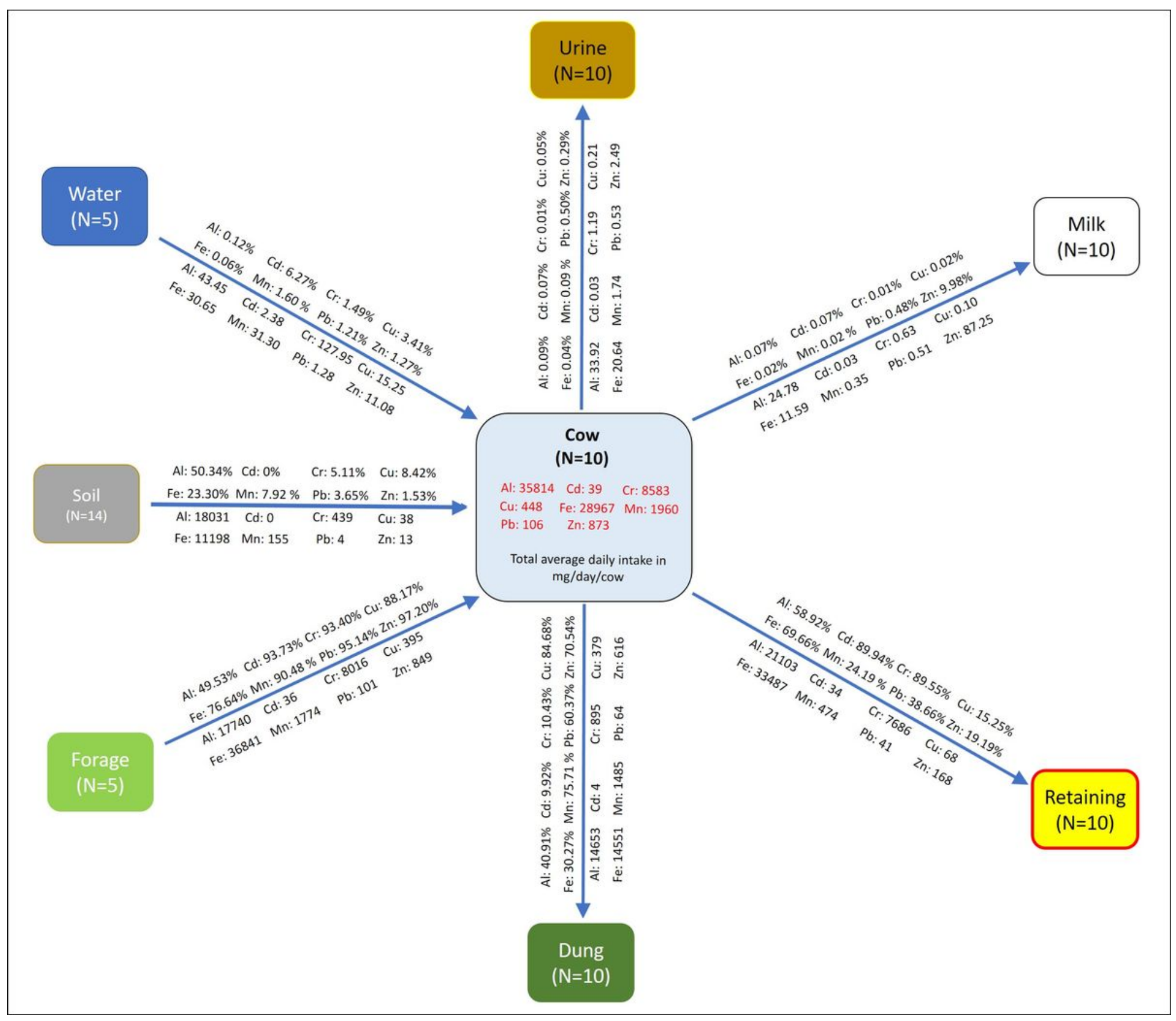

Figure 3

Mass balance chart 


\section{Incremental lifetime cancer risk (ICLR) in milk by absorption of carcinogenic metals in children}

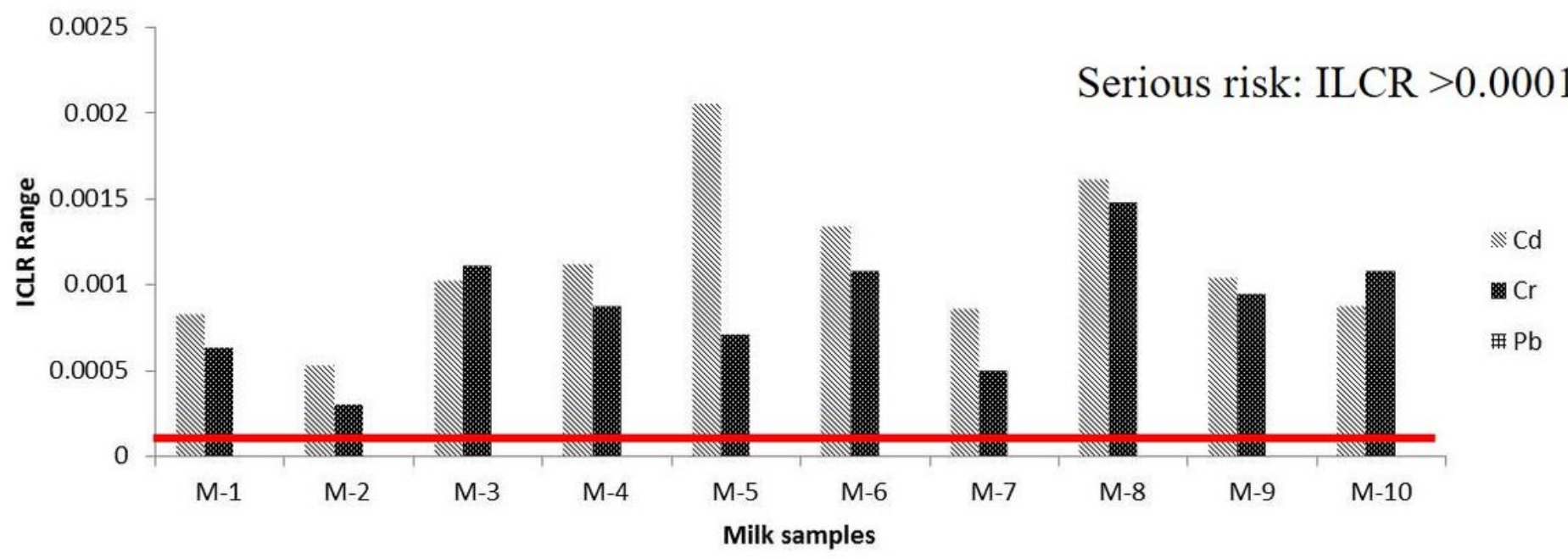

Incremental lifetime cancer risk (ICLR) in milk by absorption of carcinogenic metals in adults

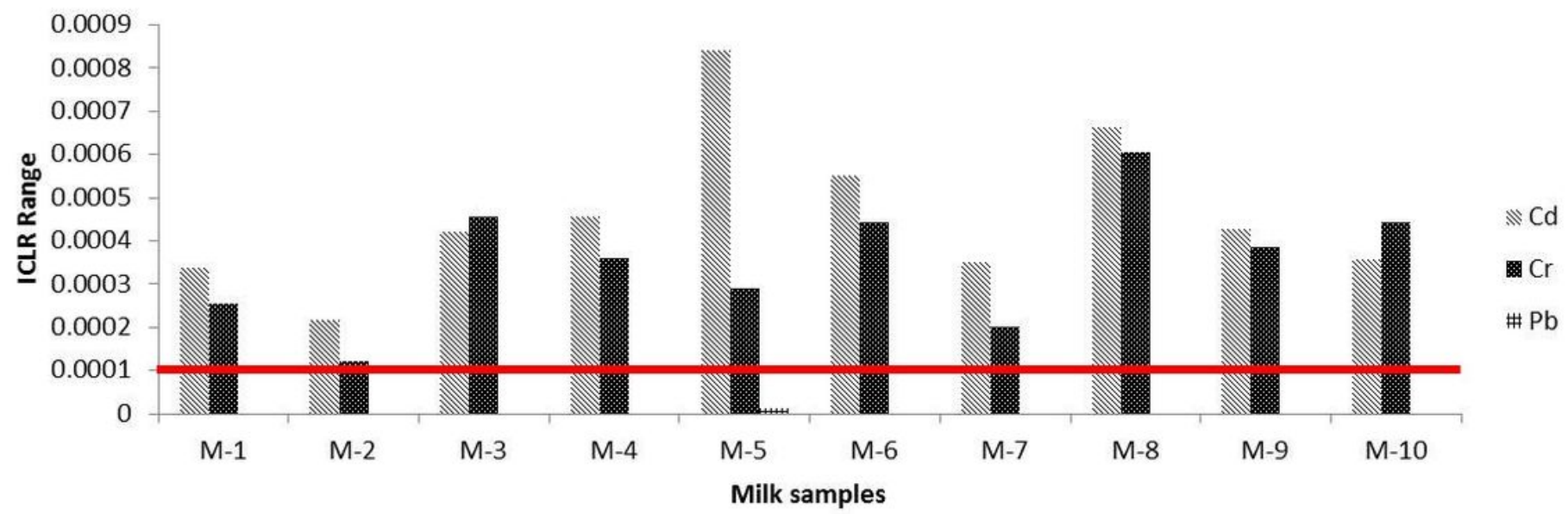

Figure 4

Incremental lifetime Cancer Risk (ILCR) in adults and children

\section{Supplementary Files}

This is a list of supplementary files associated with this preprint. Click to download.

- Supportinginformation.docx 